\title{
ANÁLISIS DEL FRACASO EMPRESARIAL POR SECTORES: FACTORES DIFERENCIADORES CROSS-INDUSTRY ANAL YSIS OF BUSINESS FAILURE: DIFFERENTIAL FACTORS
}

Ma Jesús Mures Quintana $^{1}$

mj.mures@unileon.es

Ana García Gallego ${ }^{1}$

ana.ggallego@unileon.es

$\mathrm{M}^{\mathrm{a}}$ Eva Vallejo Pascual ${ }^{1}$

eva.vallejo@unileon.es

Universidad de León

\section{Resumen}

El objetivo de este trabajo se centra en el análisis del fracaso empresarial por sectores, a fin de identificar los factores explicativos y predictivos de este fenómeno que son diferentes en tres de los principales sectores que se distinguen en toda economía: industria, construcción y servicios.

Para cada uno de estos sectores, seguimos el mismo procedimiento. En primer lugar, aplicamos un análisis de componentes principales con el que identificamos los factores explicativos del fracaso empresarial en los tres sectores. A continuación, consideramos dichos factores como variables independientes en un análisis discriminante, que aplicamos para predecir el fracaso de una muestra de empresas, utilizando no sólo información financiera en forma de ratios, sino también otras variables no financieras relativas a las empresas, así como información externa a las mismas que refleja las condiciones macroeconómicas bajo las que desarrollan su actividad.

Palabras clave: Fracaso empresarial; Ratios financieros; Información no financiera; Análisis discriminante; Sectores.

\section{Abstract}

This paper focuses on a cross-industry analysis of business failure, in order to identify the

\footnotetext{
${ }^{1}$ Facultad de Ciencias Económicas y Empresariales, Departamento de Economía y Estadística, Área de Estadística e Investigación Operativa. Universidad de León, Campus de Vegazana, 24071-León (España).
} 
explanatory and predictor factors of this event that are different in three of the main industries in every economy: manufacturing, building and service.

For each one of these industries, the same procedure is followed. First, a principal components analysis is applied in order to identify the explanatory factors of business failure in the three industries. Next, these factors are considered as independent variables in a discriminant analysis, so as to predict the firms' failure, using not only financial information expressed by ratios, but also other non-financial variables related to the firms, as well as external information that reflects macroeconomic conditions under which they develop their activity.

Keywords: Business failure; Financial ratios; Non-financial information; Discriminant analysis; Industries.

\section{INTRODUCCIÓN}

La predicción del fracaso empresarial es un importante campo de investigación dentro de la literatura financiera, que en los últimos tiempos ha adquirido gran trascendencia, debido a la severa crisis económica y financiera que está afectando a muchos países en Europa y el resto del mundo.

En este contexto de incertidumbre, las empresas, cuya actividad es la base para el desarrollo de las economías, sufren tales consecuencias que les llevan a su fracaso o crisis o, incluso, a su desaparición. Esto tiene importantes efectos en los agentes con los que la empresa se relaciona, tales como accionistas, empleados, clientes y proveedores, pero también en otros negocios que actúan en el sistema económico (Lang y Stulz, 1992), lo que puede provocar un impacto general de gran magnitud en las economías. Por tanto, se hace necesario disponer de herramientas que permitan anticipar el posible fracaso de una empresa $y$, por consiguiente, evitar los efectos que el fracaso empresarial tiene sobre los agentes económicos que participan en el sistema.

\section{INTRODUCTION}

Business failure prediction is an important research field in corporate finance literature, which has become topical in recent times, due to the serious economic and financial recession which is affecting many countries in Europe and all over the world.

In this uncertainty context, businesses, whose activity is the basis for the development of the economies, suffer from such serious consequences that lead them to their failure or crisis or even to their disappearance. That has important effects on the agents with whom the firm has relationships, such as stakeholders, employees, clients and suppliers, but also on other businesses acting in the economic system (Lang and Stulz, 1992), which can cause a general impact of great magnitude on the economies. Therefore, some tools are necessary in order to anticipate the possible failure of a firm and, consequently, to avoid the effects that business failure has on the economic agents taking part in the system. 
Este tipo de escenarios ha motivado la elaboración de modelos de predicción del fracaso empresarial, cuyo objetivo es predecir las dificultades a que una empresa pueda estar sometida, puesto que tratan de predecir el fracaso, utilizando para ello la información que las empresas publican en sus estados financieros, además de otro tipo de variables no financieras relativas a la empresa e información externa a la misma. Pero la evolución no se observa sólo en la información considerada para predecir el fracaso, sino también en las metodologías aplicadas para obtener los respectivos modelos predictivos. Desde el estudio univariante de Beaver (1966) y el primer modelo multivariante discriminante de Altman (1968), que son considerados pioneros en este campo, se han aplicado los modelos de probabilidad condicional y herramientas procedentes del campo de la inteligencia artificial, con el objetivo de mejorar los modelos elaborados con anterioridad.

Una característica común de esos modelos es la utilización de muestras heterogéneas de empresas pertenecientes a diferentes sectores o de muestras centradas en empresas que operan en el sector industrial. Este tipo de muestras parece ser la razón de la discrepancia entre los buenos resultados de clasificación ex-post y los comparativamente decepcionantes resultados de validación (ex-ante) (Smith y Liou, 2007), ya que los ratios utilizados como variables independientes pueden verse afectados por efectos sectoriales diferenciales. Es decir, "los sectores pueden diferir con respecto a los factores de producción, ciclos de vida de los productos, estructura competitiva y modos de distribución, lo que provoca diferencias en varias medidas de condición financiera" (Platt y Platt, 1990: 32).
This kind of scenarios has motivated the development of business failure prediction models, whose aim is to foresee the difficulties which a firm can face as they try to predict business failure. These models use the information in the financial statements published by the firms, as well as another kind of nonfinancial firm-related variables and other firm information from external sources. Not only is this evolution in the information considered to predict failure observed, but also in the statistical methodologies applied in order to obtain the respective prediction models. From Beaver's (1966) univariate study and Altman's (1968) first multivariate discriminant model, which are considered to be pioneering in business failure prediction research, conditional probability models and tools from artificial intelligence field have been applied, in order to improve the previously developed models.

A common figure of most of those studies is the use of heterogeneous samples of firms belonging to different industries of the economy or samples focused on firms operating in the manufacturing industry. This kind of samples seems to be the reason of discrepancy between the good ex-post classification results and the comparatively disappointing validation outcomes (exante results) (Smith and Liou, 2007), as the ratios used as independent variables can be affected by differential industry effects. That is, "industries can differ with respect to factors of production, product life cycles, competitive structure, and distribution modes which cause industry differences in various measures of financial condition" (Platt and Platt, 1990: 32). 
La influencia de los efectos sectoriales en los ratios financieros y su aplicación en la predicción del fracaso empresarial ha sido estudiada por Lincoln (1984) y McDonald y Morris (1984). El primero, a fin de medir niveles de riesgo de insolvencia, analizó cuatro sectores (industria, comercio, inmobiliario y financiero), para los que desarrolló modelos específicos de cada sector, además de un modelo combinado basado en los cuatro y modelos a partir de muestras de dos sectores, por su similitud respecto a su estructura financiera (industria-comercio e inmobiliario-financiero). Utilizando diferentes combinaciones de ratios mediante la aplicación de análisis discriminante, obtuvo que "en la mayoría de los casos la capacidad clasificatoria de las funciones obtenidas de los datos específicos de cada sector era superior a la de las derivadas de los datos de dos y de los cuatro sectores", lo que puede explicarse por "la falta de homogeneidad en los datos [...] cuando se combinan sectores" (Lincoln, 1984: 330).

McDonald y Morris (1984), por su parte, analizaron la validez estadística del método de ratios en el análisis financiero tanto en una muestra con varios sectores como en un sector homogéneo (el de servicios públicos), llegando a la conclusión de que el método es más válido para éste último, debido al hecho de que "los ratios no tienen características distributivas similares en diferentes sectores" (McDonald y Morris, 1984: 94).

Con el objetivo de tener en cuenta las diferencias entre sectores, algunas autores han adoptado un enfoque denominado "relativo al sector" (industry-relative), ajustando los ratios de las empresas por el valor mediano (Izan, 1984) o medio (Platt y Platt, 1990) para el respectivo ratio
Influence of industry effects on financial ratios and their application on business failure prediction has been studied by Lincoln (1984) and McDonald and Morris (1984). The former, in order to measure levels of insolvency risk, analysed four industries (manufacturing, retail, property, and finance), for which he developed not only single-industry models, but also a combined model based on all four, as well as other models based on twoindustry samples, due to their similarity in their financial structure (manufacturingretail and property-finance). Using different combinations of ratios in a discriminant analysis, he found that "in most cases the classification accuracy of functions derived from single-industry data was superior to those derived from two-industry data and four-industry data", which can be explained by "the lack of homogeneity in the data [..] when industries are combined" (Lincoln, 1984: 330).

McDonald and Morris (1984), on the other hand, analysed the statistical validity of the ratio method in financial analysis both in a cross-industry sample and in one homogeneous industry (the utility one), drawing the conclusion that ratio method is more valid for the latter, due to the fact that "ratios do not have similar distributional characteristics across various industries" (McDonald and Morris, 1984: 94).

In order to take into account the differences across industries, some researchers have adopted an industryrelative approach, adjusting the firms' raw ratios for the median (Izan, 1984) or the mean (Platt and Platt, 1990) value for the respective ratio in each firm's industry at a point in time. In both studies, the classification results in the models with unadjusted ratios were lower 
en el sector de cada empresa en un momento de tiempo. En ambos trabajos, los resultados de clasificación en los modelos con ratios no ajustados eran inferiores a los obtenidos con ratios ajustados al sector, confirmando que este enfoque es útil y "especialmente atractivo para modelos donde las empresas representan una extensa selección de sectores industriales" (Izan, 1984: 319).

Chava y Jarrow (2004) también evaluaron la importancia de incluir los efectos sectoriales en la predicción del fracaso, analizando diez sectores industriales principales clasificados en cuatro grupos. Incluyeron esta agrupación en los modelos mediante variables dummy, que resultaron significativas.

Otra posibilidad para solucionar el problema de las diferencias sectoriales en los ratios financieros es la elaboración de modelos específicos de predicción del fracaso empresarial referidos a un solo sector, en especial aquéllos con peculiaridades respecto a su actividad o la información que publican, como el financiero (Laffarga et al., 1985; Pina, 1989) y el asegurador (Mora, 1994). Sin embargo, hay un conjunto de trabajos sobre el sector industrial (Beaver, 1966; Altman, 1968; Deakin, 1972; Ohlson, 1980; Taffler, 1982). Estos modelos específicos tienen la ventaja de centrarse sólo en un sector, por lo que no es necesario ajustar por las diferencias sectoriales, lo que exige conocer el valor medio o mediano para cada sector incluido en una muestra que incluya varios sectores.

Con el objetivo de comprobar si había diferencias sectoriales entre las empresas españolas respecto al fracaso empresarial, Román et al. (2001) y la Junta de Andalucía (2004) han desarrollado distintos than the ones achieved with industryrelative ratios, confirming that the industry-relative approach is useful, and "particularly appealing for models where firms represent a broad cross-section of industrial sectors" (Izan, 1984: 319).

Chava and Jarrow (2004) also evaluated the importance of including industry effects in bankruptcy prediction, analysing ten major industrial sectors classified in four groups. They included this grouping into the models by using dummy variables, which resulted to be significant.

Another possibility to solve the problem of industry differences in financial ratios is the development of specific business failure prediction models referred to just one sector, especially those with peculiarities regarding their activity or the information they publish, such as the financial (Laffarga et al., 1985; Pina, 1989) or the insurance industries (Mora, 1994). However, there is a whole set of studies on the manufacturing industry (Beaver, 1966; Altman, 1968; Deakin, 1972; Ohlson, 1980; Taffler, 1982). These specific models have the advantage of focusing on one industry alone, so it is not necessary to adjust for industry differences, which requires knowing the mean or median value for each industry included in a cross-industry sample.

With the aim of proving whether there were industry differences among the Spanish firms regarding business failure, Román et al. (2001) and Junta de Andalucía (2004) have developed different prediction models in both a heterogeneous sample of firms belonging to several industries and some singleindustry samples. 
modelos predictivos, tanto en una muestra heterogénea de empresas pertenecientes a varios sectores como en muestras específicas de un sector. En general, "el grado de acierto alcanzado en el modelo global es claramente inferior a los que se llega en cada uno de los modelos sectoriales" (Román et al., 2001: 9). Asimismo, en ambos estudios puede observarse que hay factores del fracaso que son comunes a todos los sectores, pero también algunos son específicos de un sector.

Considerando el contexto descrito, el objetivo de nuestro trabajo es analizar el fracaso empresarial en España desde una perspectiva sectorial, a fin de concluir si las variables que mejor explican y describen el fracaso difieren por sectores, además de comparar los resultados de clasificación en cada sector. Para ello, consideramos un muestra de empresas de pequeño y mediano tamaño con domicilio social en la Comunidad Autónoma de Castilla y León, que dividimos en cuatro sectores principales según la actividad de las empresas, de las que recogemos tanto información financiera como variables no financieras y externas. Una vez recogida la información, aplicamos en primer lugar un Análisis de Componentes Principales (ACP), con el fin de reducir el número de variables potencialmente explicativas del fracaso empresarial. A continuación, los factores identificados los consideramos como variables independientes a entrar en una función discriminante, que obtenemos para predecir el fracaso de las empresas de la muestra en los diferentes sectores.

A fin de alcanzar nuestro objetivo, el artículo se organiza del siguiente modo: en el siguiente epígrafe hacemos referencia a la recogida de información, que implica el desarrollo de tres etapas:
In general, "the hit rate achieved in the global model is clearly lower than the ones which are obtained in each one of the single-industry models" (Román et al., 2001: 9). Furthermore, in both studies it can be observed that there are failure factors which are common to all industries, but several of them are also specific to one industry.

Taking into consideration the presented context, the aim of this paper is to analyse business failure in Spain from a cross-industry perspective, so as to conclude if the variables that best explain and predict failure are different across industries, as well as to compare the classification results in each industry. In order to do that, we consider a sample of small and medium-sized firms with head office in the region of Castile and León (Spain), which is divided into four main industries according to the firms' activity, from which we collect financial information as well as non-financial and external variables. Once information is collected, we first apply a Principal Components Analysis (PCA), so as to reduce the number of variables which can potentially explain business failure. Next, the identified factors are considered as independent variables to enter in a discriminant function, which is obtained in order to predict the failure of the firms in the sample across industries.

In order to reach our target, the paper is organised as follows: In the next section we will deal with the data collection, which involves the development of three stages: the definition of what it is understood by business failure, the sample 
la definición de lo que se entiende por fracaso empresarial, el proceso de selección de la muestra y la elección de las variables financieras y no financieras que contribuyen a explicar y predecir el fenómeno del fracaso. En el epígrafe 3 presentamos los resultados empíricos obtenidos en las diferentes muestras de empresas que operan en cada sector, tanto respecto a la selección de variables mediante el ACP como los resultados predictivos obtenidos con la aplicación del análisis discriminante. El trabajo finaliza con las principales conclusiones extraídas del mismo.

\section{RECOGIDA DE INFORMACIÓN}

La primera etapa en el desarrollo de un modelo de predicción del fracaso empresarial es la recogida de información necesaria para obtener el modelo. Puesto que el objetivo de cualquiera de estos modelos es identificar las variables que mejor discriminan entre empresas fracasadas y no fracasadas, la muestra de estudio debe incluir ambos tipos de empresas. Por tanto, antes de proceder a seleccionar la muestra, es preciso decidir lo que se entiende por fracaso empresarial, ya que hay una variedad de situaciones con influencia negativa en la actividad empresarial que podrían considerarse como definición de este fenómeno.

Una vez definido el fracaso empresarial, seleccionamos la muestra objeto de estudio. A diferencia de la mayoría de modelos previos, que han utilizado una muestra emparejada con el mismo número de empresas fracasadas y no fracasadas, seleccionamos una muestra aleatoria, sobre la base del tamaño y composición de la población. Elegida la muestra, la dividimos en tres de los principales sectores que se distinguen en toda economía: industria, construcción y servicios, a fin de obtener un modelo predictivo diferente para cada sector. selection process, and the choice of the financial and non-financial variables that help explain and predict the failure event. Section 3 introduces and discusses the empirical results in the different samples of firms operating in each industry, referring to both the selection of variables by PCA and the prediction results achieved by discriminant analysis. The paper concludes with the summary remarks.

\section{DATA COLLECTION}

The first step in the development of a business failure prediction model is the collection of the data that are necessary to obtain the model. Provided the aim of any of these models is to identify the variables that best discriminate between failed and non-failed firms, the study sample must include both kinds of firms. Therefore, before selecting the sample, it is important to decide what it is understood by business failure, since there are a variety of situations with a negative influence on firms' activity, all of them could be considered as a definition of that event.

Once business failure is defined, the study sample is selected. Unlike most of the previous models, which have used a paired sample with the same number of failed and non-failed firms, a random sample is chosen, based on the population size and composition. Once it is selected, we divide it into three of the main industries in every economy: manufacturing, building and service, in order to develop a different prediction model for each industry. 
Con el fin de desarrollar los modelos, es necesario considerar un conjunto de variables que contribuyen a explicar y predecir el fracaso. Además de ratios financieros, que reflejan la actividad de las empresas, ya que se calculan a partir de sus estados financieros, es importante tener en cuenta otro tipo de información no financiera que también influye en el futuro fracaso de una empresa.

\subsection{Definición de fracaso empresarial}

Como hemos mencionado, la primera decisión a tomar en el desarrollo de un modelo de predicción del fracaso empresarial corresponde a la definición de lo que se entiende por dicho fenómeno.

Es evidente que el fracaso empresarial hace referencia a una situación negativa que afecta a la actividad empresarial. Una revisión de la literatura previa ${ }^{2}$ en este campo pone de manifiesto la existencia de diferentes definiciones de fracaso, según el objetivo del respectivo trabajo, que a su vez se define atendiendo a las necesidades de los potenciales usuarios de cada modelo. Si una empresa fracasa, las consecuencias que conlleva sobre los distintos agentes implicados en la empresa (como inversores, prestamistas y proveedores, clientes, trabajadores, gerentes o auditores) son diferentes. Por consiguiente, el fenómeno que se utilice como definición de tal situación también debería ser diferente, puesto que los mencionados agentes son los potenciales usuarios de cualquier modelo de predicción del fracaso y cada uno busca una aplicación diferente cuando utiliza el modelo a efectos de predecir el fracaso empresarial.

\footnotetext{
${ }^{2}$ Además de los trabajos citados en este artículo, un resumen de los modelos más relevantes desarrollados tanto en Estados Unidos como en otros países europeos y de todo el mundo puede encontrarse en las revisiones bibliográficas realizadas por Altman (1984), Dimitras et al. (1996), Cybinski (2001) ó Ravi Kumar \& Ravi (2007).
}

To develop the models, it is necessary to consider a set of variables that contribute to explain and predict failure. As well as financial ratios, which reflect the firms' activity out of their financial statements, it is important to take into account other kind of non-financial information that also has an influence on a firm's future failure.

\subsection{Definition of business failure}

As it has been said, the first decision in the development of a business failure prediction model is stating the definition of what it is understood by that event.

It is clear that business failure refers to a negative situation affecting a firm's activity. A review of the previous literature $^{3}$ in this field shows different definitions of failure, depending on the aim of the respective model, defined according to the needs of the potential users. If a firm fails, the consequences on the different parties involved in the firm (such as investors, lenders and suppliers, clients, employees, managers or auditors) are different. Therefore, the event used as a definition of this situation should also be different, provided those parties are the potential users of any prediction model and they seek a different applicability when using the model in order to predict business failure.

\footnotetext{
${ }^{3}$ As well as the cited works in the paper, a summary of the most relevant models developed both in the United States and other European and all over the world countries can be found in the literature reviews published by Altman (1984), Dimitras et al. (1996), Cybinski (2001) or Ravi Kumar \& Ravi (2007).
} 
Entre las definiciones más utilizadas en los principales estudios realizados podemos considerar las siguientes:

- la declaración formal de quiebra o cualquier otro procedimiento legal (Altman, 1968; Taffler, 1982; Laffarga et al., 1985; Ohlson, 1980; Zmijewski, 1984; Peel et al., 1986; Pina, 1989; Theodossiou, 1991; Odom y Sharda, 1992; Dimitras et al., 1999; Charitou et al., 2004);

- fracaso en el sentido de insolvencia, como la incapacidad de la empresa para pagar sus deudas a medida que vencen (Edmister, 1972; Laitinen, 1991), o

- un conjunto de situaciones diferentes, además de las dos anteriores (Altman et al., 1994; Laitinen y Laitinen, 1998), como el descubierto bancario y la falta de pago a accionistas preferentes (Beaver, 1966; Deakin, 1972) o un acuerdo explícito con los acreedores para reducir deudas (Blum, 1974; Elam, 1975).

Como puede observarse, hay un gran listado de situaciones negativas que pueden considerarse como definición del fracaso empresarial. Sin embargo, la mayoría de modelos han utilizado una definición jurídica del fracaso, ya sea quiebra o liquidación o cualesquiera otros conceptos, según la legislación vigente en cada país, debido a la ventaja de ser un acontecimiento sumamente evidente que puede fecharse de manera objetiva (Keasey y Watson, 1991). Además, la mayoría de modelos contienen ratios financieros como variables independientes para predecir el fracaso, por lo que esta definición evitaría los problemas que podría ocasionar el hecho de que tanto las variables predictoras como el suceso que tratan de predecir estuvieran basados en los mismos estados financieros, si se utilizara un criterio más económico, como el nivel de ingresos o la posición de liquidez (Jones, 1987).
Among the most widespread definitions in the mainstream studies we can consider the following ones:

- A firm's formal declaration of bankruptcy or another legal proceeding (Altman, 1968; Taffler, 1982; Laffarga et al., 1985; Ohlson, 1980; Zmijewski, 1984; Peel et al., 1986; Pina, 1989; Theodossiou, 1991; Odom and Sharda, 1992; Dimitras et al., 1999; Charitou et al., 2004);

- Failure in the sense of insolvency, as the inability of a firm to pay debts as they fall due (Edmister, 1972; Laitinen, 1991), or

- A group of different situations, as well as the two previous ones (Altman et al., 1994; Laitinen and Laitinen, 1998), such as an overdrawn account and the nonpayment of a preferred stock dividend (Beaver, 1966; Deakin, 1972) or an explicit agreement with creditors to reduce debts (Blum, 1974; Elam, 1975).

As it can be observed, there is a large list of negative situations that can be considered as a definition of business failure. Nevertheless, the majority of the developed models have used a juridical definition of failure, either bankruptcy or liquidation or whatever other used concepts, attending the current legislation in each country, because it has the advantage of being a highly visible event that can be objectively dated (Keasey and Watson, 1991). Furthermore, most models contain financial ratios as independent variables to predict failure, so this definition would avoid the problems involved by the fact that both the predictor variables and the event they try to predict are based on the same financial statements if a more economic criterion, such as income level or liquidity position, was used (Jones, 1987). 
Teniendo en cuenta las ventajas de la definición legal de fracaso sobre otras situaciones negativas que afectan a la actividad de las empresas, también consideramos esta situación como subrogado del fracaso empresarial, definiendo éste como la declaración formal, por parte de la empresa, de uno de los tres posibles procedimientos concursales recogidos en la legislación española, y que están incluidos bajo el término general de bankruptcy.

\subsection{Muestra de empresas}

El siguiente paso en el desarrollo de los modelos de predicción del fracaso es la selección de la muestra. Para ello, nos centramos en la Comunidad Autónoma de Castilla y León y utilizamos la base de datos SABI para recoger la información relativa a la muestra seleccionada.

El objetivo de nuestro estudio es comparar el fracaso empresarial en tres de los principales sectores que pueden identificarse en toda economía: industria, construcción y servicios. Sin embargo, con el fin de seleccionar una muestra representativa de la población, en primer lugar consideramos toda la población de empresas en la base de datos y, una vez seleccionada una muestra aleatoria de empresas, la dividimos en tres submuestras según la actividad de cada empresa.

En los modelos desarrollados con anterioridad, el método de muestreo más utilizado ha sido el de obtener una muestra denominada "basada en el estado" (state-based sample, Zmijewski 1984), ya que consiste en seleccionar la muestra de empresas fracasadas, según la definición de fracaso empresarial considerada, y emparejarlas con empresas sanas del mismo sector y tamaño, lo que resulta en una muestra constituida por el
Taking into consideration the advantages of the legal definition of failure over other negative situations affecting firms' activity, we also consider this state as a surrogate of business failure, defining this as the firm's formal declaration of one of the three possible proceedings in the Spanish law, which are included under the general terminology of bankruptcy.

\subsection{Sample of firms}

The next step forward in the development of prediction models is the sample selection. In order to do that, we focused on the region of Castile and León (Spain) and used the database SABI to collect the information related to the selected sample.

The target of our study is to compare business failure in three of the main industries that can be identified in every economy: manufacturing, building and service. Nevertheless, in order to select a representative sample of the population, we first consider the whole firms' population in the database. Once a random sample of firms is selected, we divide it into the three subsamples according to each firm's activity.

In the previously developed models, the most common sampling method has been to derive a so-called state-based sample (Zmijewski, 1984), which consists in selecting the sample of failed firms, according to the used definition of business failure. Next, these firms are matched to the non-failed ones devoted to the same industry and being of the same size, which results in a sample composed by the same number of companies in both groups. This kind of 
mismo número de empresas en los dos grupos. Si bien esta clase de muestra tiene la ventaja de asegurar un número suficiente de empresas fracasadas, pues hay una baja tasa de empresas que fracasan en la economía, se obtiene aplicando un método de muestreo no aleatorio que no respeta las proporciones poblacionales en la muestra, cuando los métodos estadísticos clásicos que se utilizan en los modelos de predicción del fracaso están basados en un diseño muestral aleatorio (Balcaen y Ooghe, 2006). Por consiguiente, los estimadores de los parámetros son inconsistentes y sesgados, lo que lleva a una sobrestimación de la capacidad predictiva del modelo (Palepu, 1986), ya que la tasa de error para las empresas fracasadas está subestimada (Balcaen y Ooghe, 2006).

Con el fin de solventar todos los inconvenientes planteados, aplicamos un procedimiento de muestreo "mixto", que combina las ventajas tanto del muestreo aleatorio como no aleatorio. En primer lugar, identificamos la población de empresas en la base de datos SABI, utilizada para la recogida de información, con el requisito de disponibilidad en la misma de los estados financieros para un periodo de tres ejercicios económicos consecutivos.

Teniendo en cuenta el criterio elegido para el fracaso empresarial, identificamos 59 empresas fracasadas. Debido a la baja tasa de fracaso en la población (un total de 41.584 compañías), elegimos estas 59 empresas para formar la muestra de fracasadas, como una especie de muestreo no aleatorio, a fin de asegurar un número suficientemente grande de este grupo de empresas en la misma. Respecto a las empresas sanas o no fracasadas, seleccionamos una muestra aleatoria, sobre la base del tamaño y la composición de la población. Utilizando sample has the advantage of assuring a big enough number of failed firms, as there is a low frequency rate of failing firms in the economy. However, it is obtained by applying a non-random sampling method that does not respect the population proportions in the sample. On the contrary, classical statistical methods used in failure prediction models are based on the assumption of a random sampling design (Balcaen and Ooghe, 2006). Therefore, parameter estimates are inconsistent and biased, which leads to an overstatement of the model's ability to predict (Palepu, 1986), as the misclassification error rate for the failed firms is understated (Balcaen and Ooghe, 2006).

In order to solve all these drawbacks, we applied a "mixed" sample derivation, which combines the advantages of both random and non-random sampling. First of all, we identified the firms' population in the database SABI, used to collect the information, with the requirement of availability of financial statements for three consecutive economic years.

Taking into account our criterion for business failure, there were 59 failed firms. Due to the low failure rate in the population (41,584 companies altogether), we chose the 59 firms to derive the failed sample, as a kind of non-random sampling, in order to ensure a big enough number of firms in this group. Regarding the non-failed firms, a random sample was selected, on the basis of their population size and composition. Using the formulae appropriate to calculate the size for the non-failed firms group, it resulted in a sample size of 396 companies. In order to respect characteristics and peculiarities 
la fórmula adecuada para determinar el tamaño de este grupo de empresas, resultó un tamaño muestral de 396 compañías. Por otro lado, al objeto de respetar las características y peculiaridades de los diferentes sectores, las empresas no fracasadas fueron seleccionadas del mismo sector en que operaban las empresas fracasadas, atendiendo al tamaño poblacional en cada uno.

Una vez seleccionada la muestra total, cada empresa fue clasificada según su actividad, tal como están codificadas en la Clasificación Nacional de Actividades Económicas (CNAE-93) a nivel de dos dígitos. Atendiendo a esta clasificación, la muestra fue dividida en cuatro submuestras, correspondientes a los cuatro sectores principales identificados en toda economía: agricultura, industria, construcción y servicios, tal como puede observarse en la Tabla 1, donde se recoge un resumen de la muestra objeto de estudio. of different industries, non-failed firms were selected from the same industry in which failed companies developed its activity, according to each industry population size.

Once the total sample was selected, each firm was classified according to their activity as it is coded in the Spanish Industrial Classification Code (CNAE-93) considering two digits. Taking into account this classification, the sample was divided into four subsamples, corresponding to the four main industries identified in every economy: agriculture, manufacturing, building and service, as it can be observed in Table 1, where there is a summary of the study sample.

Tábla 1. Muestra de empresas / Table 1. Fims' sample

\begin{tabular}{|c|c|c|c|c|c|}
\hline \multicolumn{2}{|c|}{ Sector económico / Industry } & \multicolumn{2}{c|}{$\begin{array}{c}\text { Empresas fracasadas } \\
\text { Failed firms }\end{array}$} & \multicolumn{2}{c|}{$\begin{array}{c}\text { Empresas no fracasadas } \\
\text { Non-failed firms }\end{array}$} \\
\hline $\begin{array}{c}\text { Actividad } \\
\text { principal } \\
\text { Activity }\end{array}$ & $\begin{array}{c}\text { Código CNAE- } \\
\text { 93 I CNAE-93 } \\
\text { Code }\end{array}$ & $\begin{array}{c}\text { Número } \\
\text { Number }\end{array}$ & $\begin{array}{c}\text { Porcentaje } \\
\text { Percentage }\end{array}$ & $\begin{array}{c}\text { Número } \\
\text { Number }\end{array}$ & $\begin{array}{c}\text { Porcentaje } \\
\text { Percentage }\end{array}$ \\
\hline $\begin{array}{c}\text { Agricultura } \\
\text { Agriculture }\end{array}$ & 01 & 5 & 8,5 & 14 & 3,5 \\
\hline $\begin{array}{c}\text { Industria } \\
\text { Manufacturing }\end{array}$ & $14-36$ & 22 & 37,3 & 59 & 14,9 \\
\hline $\begin{array}{c}\text { Construcción } \\
\text { Building }\end{array}$ & 45 & 12 & 20,3 & 85 & 21,5 \\
\hline $\begin{array}{c}\text { Servicios } \\
\text { Service }\end{array}$ & $50-85$ & 20 & 33,9 & 238 & 60,1 \\
\hline \multicolumn{2}{|c|}{ Total } & 59 & 100 & 396 & 100 \\
\hline
\end{tabular}


Debido al bajo número de empresas en el sector de la agricultura, decidimos eliminarlo del estudio y realizar el análisis respecto a los otros tres sectores, con el objetivo de comparar los resultados sobre fracaso empresarial en cada sector.

\subsection{Variables del estudio}

Dado que el objetivo de nuestro estudio es caracterizar el fracaso empresarial en cada uno de los tres sectores identificados en la muestra total, es necesario seleccionar un conjunto de variables que se supone discriminan entre empresas fracasadas y no fracasadas, contribuyendo de este modo a la explicación y predicción del fenómeno de interés.

En primer lugar, es obvio que el fracaso de una empresa depende fundamentalmente de la actividad que desarrolla, que se refleja en la información que publica en sus estados financieros. Por tanto, el primer tipo de información a considerar para predecir el fracaso es una variedad de ratios financieros que se calculan relacionando diferentes partidas contables, como una forma más fácil de tratar toda la información financiera contenida en los estados contables. Debido a la falta de una teoría económica sobre fracaso empresarial que sirviera de guía para elegir ratios, la selección ha sido básicamente empírica, basada en su popularidad en la literatura y en su frecuencia y nivel de significación en la investigación previa, en la línea iniciada por Beaver (1966), si bien la consideración de estos criterios ha dado lugar a un amplio listado de ratios potencialmente explicativos del fracaso empresarial.

En un intento por reducir ese gran número, para seleccionar los ratios financieros de nuestro estudio nos hemos limitado a los ratios utilizados (y que
Due to the small number of firms in the agriculture industry, we decided to eliminate it from the study and to run the analysis concerning the other three industries, with the aim of comparing the results regarding business failure in each industry.

\subsection{Variables of study}

Provided the target of our study is to characterize business failure in each of the three industries identified in the total sample, it is necessary to choose a set of variables that are supposed to discriminate between failed and non-failed firms, contributing in that way to the explanation and prediction of the event of interest.

First of all, it is obvious that a firm's failure mainly depends on the activity it develops, which is reflected in the information published in its financial statements. Therefore, the first type of information to consider when predicting failure is a variety of financial ratios that are computed relating different accounting entries, as an easier way of treating all the financial information in the statements. Due to the lack of an economic theory of business failure that could be a guide to select ratios, the selection has been basically empirical, based on their popularity in literature and their use and predictive success in previous research, as Beaver (1966) did, although the use of these criteria has resulted in a huge list of ratios potentially explanatory of business failure.

In an attempt to reduce that large list, in order to select the financial ratios for our study we have limited to the ratios used (and significant) in several of the previously developed models and especially those of 
resultaron significativos) en varios de los modelos desarrollados previamente y en especial los de Beaver (1966) y Altman (1968), dado que sus trabajos son considerados pioneros en este campo y sus ratios han sido utilizados en gran cantidad de modelos desarrollados con posterioridad.

En todo caso, la selección de variables también ha estado influenciada por la disponibilidad de información para las empresas de la muestra, puesto que la información fue recogida para un periodo de tres ejercicios consecutivos: en el caso de las empresas fracasadas, el periodo de tres años anteriores al fracaso y los tres últimos años de actividad, para las no fracasadas.
Beaver (1966) and Altman (1968), provided they are considered to be pioneering in this field and because most of their ratios have also been used in a big number of subsequently developed models.

In any case, the variable selection has also been influenced by information availability for the firms in our sample, since the information was collected for a period of three consecutive years: in the case of failed firms the three-year period before failure, and the last three years of activity for the non-failed ones.

\section{Tabla 2. Ratios financieros utilizados como variables independientes Table 2. Financial ratios used as independent variables}

\begin{tabular}{|c|c|c|}
\hline $\begin{array}{l}\text { Categoría } \\
\text { Category }\end{array}$ & $\begin{array}{l}\text { Nombre } \\
\text { Name }\end{array}$ & Definición / Definition \\
\hline \multirow{5}{*}{$\begin{array}{l}\text { Liquidez } \\
\text { Liquidity }\end{array}$} & $\mathrm{RCl}$ & $\begin{array}{l}\text { Ratio de circulante o liquidez general: Activo circulante } \div \text { Pasivo circulante } \\
\text { Current ratio: Current assets } \div \text { Current liabilities }\end{array}$ \\
\hline & PAC & $\begin{array}{l}\text { Prueba ácida: (Activo circulante }- \text { Existencias) } \div \text { Pasivo circulante } \\
\text { Acid test: (Current assets - Inventories) } \div \text { Current liabilities }\end{array}$ \\
\hline & LIQ & $\begin{array}{l}\text { Liquidez inmediata: Disponible (Tesorería) } \div \text { Pasivo circulante } \\
\text { Quick ratio: Cash } \div \text { Current liabilities }\end{array}$ \\
\hline & CCA & $\begin{array}{l}\text { Capital circulante: Capital circulante } \div \text { Activo total } \\
\text { Working capital } \div \text { Total assets }\end{array}$ \\
\hline & CCFO & Capital circulante: Capital circulante $\div$ Fondos propios / Working capital $\div$ Equity \\
\hline \multirow{4}{*}{$\begin{array}{l}\text { Rentabilidad } \\
\text { Profitability }\end{array}$} & ROA & $\begin{array}{l}\text { Rentabilidad económica: Resultado del ejercicio } \div \text { Activo total } \\
\text { Return on assets: Net income } \div \text { Total assets }\end{array}$ \\
\hline & ROE & $\begin{array}{l}\text { Rentabilidad financiera: Resultado del ejercicio } \div \text { Fondos propios } \\
\text { Return on equity: Net income } \div \text { Equity }\end{array}$ \\
\hline & REAC & $\begin{array}{l}\text { Rentabilidad sobre fondos de accionistas: Resultado antes de impuestos } \div \\
\text { Fondos propios / Earnings before taxes } \div \text { Equity }\end{array}$ \\
\hline & ROAll & $\begin{array}{l}\text { Rentabilidad económica: Resultado antes de impuestos } \div \text { Activo total } \\
\text { Earnings before taxes } \div \text { Total assets }\end{array}$ \\
\hline
\end{tabular}


Análisis del fracaso empresarial por sectores: factores diferenciadores Cross-industry analysis of business failure: Differential factors

\begin{tabular}{|c|c|c|}
\hline \multirow{8}{*}{$\begin{array}{l}\text { Endeudamiento y } \\
\text { solvencia } \\
\text { Leverage and } \\
\text { solvency }\end{array}$} & REP & $\begin{array}{l}\text { Nivel de endeudamiento: Pasivo exigible } \div \text { Activo total } \\
\text { Total liabilities } \div \text { Total assets }\end{array}$ \\
\hline & RECP & $\begin{array}{l}\text { Endeudamiento a corto plazo: Pasivo circulante } \div \text { Activo total } \\
\text { Current liabilities } \div \text { Total assets }\end{array}$ \\
\hline & RELP & $\begin{array}{l}\text { Endeudamiento a largo plazo: Pasivo fijo } \div \text { Activo total } \\
\text { Fixed liabilities } \div \text { Total assets }\end{array}$ \\
\hline & NPA & $\begin{array}{l}\text { Autonomía financiera (solvencia): Fondos propios } \div \text { Activo total } \\
\text { Equity } \div \text { Total assets }\end{array}$ \\
\hline & FPPC & Fondos propios $\div$ Pasivo circulante / Equity $\div$ Current liabilities \\
\hline & EQUI & $\begin{array}{l}\text { Cobertura de inmovilizado o equilibrio: (Fondos propios + Pasivo fijo) } \div \\
\text { Activo fijo / (Equity + Fixed liabilities) } \div \text { Fixed assets }\end{array}$ \\
\hline & CCF & $\begin{array}{l}\text { Cobertura de cargas financieras: Resultado de explotación } \div \text { Gastos } \\
\text { financieros / Operating result } \div \text { Financial expenses }\end{array}$ \\
\hline & GFV & $\begin{array}{l}\text { Cobertura de cargas financieras: Gastos financieros } \div \text { Importe neto cifra de } \\
\text { ventas / Financial expenses } \div \text { Sales }\end{array}$ \\
\hline \multirow{4}{*}{$\begin{array}{l}\text { Rotación y } \\
\text { actividad } \\
\text { Turnover and } \\
\text { activity }\end{array}$} & RAC & $\begin{array}{l}\text { Rotación de activo: Importe neto de la cifra de ventas (INCV) } \div \text { Activo total } \\
\text { Sales } \div \text { Total assets }\end{array}$ \\
\hline & $\operatorname{Var}(\mathrm{INCV})$ & Crecimiento de la cifra de ventas: $I N C V_{t} \div \mathrm{INCV}_{\mathrm{t}-1} /$ Salest $_{t} \div$ Salest-1 \\
\hline & $\mathrm{CCV}$ & Capital circulante $\div$ Importe neto de la cifra de ventas / Working capital $\div$ Sales \\
\hline & PPAG & $\begin{array}{l}\text { Rotación de activo circulante: Activo circulante } \div \text { Ingresos de explotación } \\
\text { Current assets } \div \text { Operating income }\end{array}$ \\
\hline \multirow{3}{*}{$\begin{array}{l}\text { Recursos } \\
\text { generados } \\
\text { Cash-flow }\end{array}$} & CFAT & $\begin{array}{l}\text { Recursos generados sobre estructura económica: Cash-flow } \div \text { Activo total } \\
\text { Cash flow } \div \text { Total assets }\end{array}$ \\
\hline & CFDT & $\begin{array}{l}\text { Capacidad de devolución de la deuda: Cash-flow } \div \text { Pasivo exigible } \\
\text { Cash flow } \div \text { Total liabilities }\end{array}$ \\
\hline & CFPC & $\begin{array}{l}\text { Capacidad de devolución de la deuda a corto plazo: Cash-flow } \div \text { Pasivo } \\
\text { circulante / Cash flow } \div \text { Current liabilities }\end{array}$ \\
\hline \multirow{3}{*}{$\begin{array}{l}\text { Estructura } \\
\text { Economic } \\
\text { structure }\end{array}$} & $\mathrm{AC}$ & Activo circulante $\div$ Activo total / Current assets $\div$ Total assets \\
\hline & AF & Activo fijo $\div$ Activo total / Fixed assets $\div$ Total assets \\
\hline & TES & Tesorería $\div$ Activo total / Cash $\div$ Total assets \\
\hline
\end{tabular}

Todos los criterios señalados resultan en un listado final de 27 ratios financieros, que son clasificados en los tradicionales grupos de liquidez, rentabilidad, endeudamiento y solvencia, rotación y actividad, cash-flow y estructura. Aparecen recogidos en la Tabla 2 , junto con su respectiva definición.

Además de ratios financieros, la información no financiera también tiene influencia en el fracaso empresarial, por lo que su inclusión en los modelos de predicción podría mejorar los resultados obtenidos cuando sólo se consideran variables financieras. En este sentido, Jones (1987) señala que no hay razón para limitar el estudio a
All the mentioned criteria result in a final list composed of 27 financial ratios, which are classified in the traditional groups of liquidity, profitability, leverage and solvency, turnover and activity, cash-flow, and economic structure. They are shown in Table 2, together with their respective definition.

As well as financial ratios, non-financial information also has an influence on failure business, so its inclusion in the prediction models could improve the results achieved when considering only financial variables. In this sense, Jones (1987) pointed out that there is no reason to limit the study to 
los ratios financieros y que los modelos multivariantes podrían incrementar su poder predictivo incorporando otro tipo de información, como variables cualitativas y macroeconómicas. Esta es la razón por la que consideramos como potenciales variables independientes para predecir el fracaso variables no financieras relativas a la empresa, cuya definición se recoge en la Tabla 3.

Por otro lado, las empresas desarrollan su actividad bajo ciertas condiciones macroeconómicas, por lo que es importante considerar este tipo de información en cualquier modelo de predicción del fracaso. Estas variables externas tratan de medir el estado general de la economía y están definidas como la variación porcentual respecto al año anterior, como puede observarse en la Tabla 3. financial ratios and that multivariate models could increase prediction power by incorporating another kind of information, such as qualitative and macroeconomic variables. That is the reason why we consider as potential independent variables to predict failure other firm-related nonfinancial variables whose definition is shown in Table 3.

On the other hand, firms develop their activity under some specific macroeconomic conditions, so it is important to take into consideration this kind of information in any business failure model. These external variables try to measure the general state of the economy and are defined as the percentage change on previous year, as it can also be observed in Table 3 .

\section{Tabla 3. Variables independientes no financieras Table 3. Non-financ ial independent variables}

\begin{tabular}{|c|c|c|}
\hline $\begin{array}{l}\text { Categoría } \\
\text { Category }\end{array}$ & $\begin{array}{l}\text { Nombre } \\
\text { Name }\end{array}$ & Definición / Definition \\
\hline \multirow{4}{*}{$\begin{array}{l}\text { Relativas a } \\
\text { la empresa } \\
\text { Firm-related }\end{array}$} & VIDA & $\begin{array}{l}\text { Tiempo (en meses) desde la constitución de la empresa } \\
\text { Time (in months) from firm incorporation date }\end{array}$ \\
\hline & FORMA & $\begin{array}{l}\text { 1, si la empresa es sociedad de responsabilidad limitada; } 0 \text {, si es sociedad anónima } \\
1 \text {, if the firm is a private limited company (Ltd); } 0 \text {, if it is a public limited company (p/c) }\end{array}$ \\
\hline & AÑO & Último año disponible de las cuentas anuales / Year of last financial statements \\
\hline & SECTOR & $\begin{array}{l}\text { Sector de actividad, a nivel de dos dígitos de la CNAE-93 / Firm economic activity } \\
\text { industry, defined by two-digit Spanish Industrial Classification code (CNAE-93) }\end{array}$ \\
\hline \multirow{8}{*}{$\begin{array}{l}\text { Externas } \\
\text { External }\end{array}$} & PIB_Nac & $\begin{array}{l}\text { Variación porcentual del Producto Interior Bruto (a nivel nacional) } \\
\text { Percentage change in Gross National Product }\end{array}$ \\
\hline & IPI_Nac & $\begin{array}{l}\text { Variación porcentual del Índice de Precios Industriales a nivel nacional } \\
\text { Percentage change in National Producer Price Index }\end{array}$ \\
\hline & IPI_CyL & $\begin{array}{l}\text { Variación porcentual del Índice de Precios Industriales en Castilla y León } \\
\text { Percentage change in Castilla y León Producer Price Index }\end{array}$ \\
\hline & IPC_Nac & $\begin{array}{l}\text { Variación porcentual del Índice de Precios de Consumo a nivel nacional } \\
\text { Percentage change in National Consumer Price Index }\end{array}$ \\
\hline & IPC_CyL & $\begin{array}{l}\text { Variación porcentual del Índice de Precios de Consumo en Castilla y León } \\
\text { Percentage change in Castilla y León Consumer Price Index }\end{array}$ \\
\hline & Tac_Nac & $\begin{array}{l}\text { Variación porcentual de la Tasa de actividad a nivel nacional } \\
\text { Percentage change in National Activity Rate }\end{array}$ \\
\hline & Tac_CyL & $\begin{array}{l}\text { Variación porcentual de la Tasa de actividad en Castilla y León } \\
\text { Percentage change in Castilla y León Activity Rate }\end{array}$ \\
\hline & Tip_inte & $\begin{array}{l}\text { Variación porcentual del Tipo de interés legal del dinero } \\
\text { Percentage change in Legal Interest Rate }\end{array}$ \\
\hline
\end{tabular}




\section{ESTUDIO EMPÍRICO: ANÁLISIS DE RESULTADOS}

Una vez seleccionada la muestra y recogida la información correspondiente a las variables independientes, elaboramos un modelo de predicción del fracaso empresarial para cada sector mediante la aplicación del análisis discriminante, en el que consideramos como variables predictoras los ratios financieros y la información no financiera. Como paso previo, aplicamos un $A C P$, a fin de identificar aquellos factores con un alto poder explicativo del fracaso empresarial y reducir el número de variables seleccionadas como potencialmente predictoras de este fenómeno.

\subsection{Selección de variables: Análisis de Componentes Principales (ACP)}

El principal objetivo del ACP es obtener un conjunto de factores que resumen la información proporcionada por las variables independientes, lo que nos permite reducir el número de variables a entrar en los modelos predictivos.

Como hemos señalado, consideramos tres tipos de variables: ratios financieros, información no financiera relativa a la empresa y variables externas. Por lo que se refiere a la información relativa a la empresa, sólo FORMA y VIDA fueron consideradas como variables potencialmente explicativas, puesto que la variable AÑO fue tenida en consideración al seleccionar la muestra y estamos desarrollando un modelo para cada sector (variable SECTOR). Por tanto, debido a su pequeño número, las consideramos directamente como variables independientes a entrar en la función discriminante y aplicamos el ACP sólo sobre los ratios financieros y las variables externas.

\section{EMPIRICAL ANALYSIS AND RESULTS}

Once the study sample was selected and the information concerning the independent variables collected, a business failure prediction model for each industry was developed by applying a discriminant analysis, where financial ratios and nonfinancial information were considered as predictor variables. As a previous step, a PCA was applied in order to identify those factors with a high explanatory power over business failure and reduce the number of variables chosen as potentially predictor of this event.

\subsection{Variable selection: Principal Components Analysis (PCA)}

The main target of the PCA is to obtain a set of factors summarizing the information provided by the independent variables, which allows us to reduce the number of variables to enter the prediction models.

As it has been mentioned, three kinds of variables are considered: financial ratios, non-financial firm-related information and external variables. Regarding the firm-related information, only FORMA and VIDA were considered as potentially predictor variables, since AÑO was taken into consideration in the sample derivation and we are developing a prediction model for each industry (variable SECTOR). Therefore, due to their small number, they were directly considered as independent variables to enter the discriminant function and PCA was only applied on the financial ratios and external variables. 
En primer lugar, aplicamos el análisis sobre la información financiera y externa, pero observamos un comportamiento claramente diferenciado entre los ratios financieros, por un lado, y las variables externas, por otro. Por consiguiente, decidimos desarrollar el análisis por separado con las variables pertenecientes a cada grupo.

En el caso de la información financiera, el ACP se aplicó sobre el listado inicial de 27 ratios, referidos al último año del periodo en estudio. Aquellos ratios no correlacionados con ninguno de los factores extraídos fueron eliminados en pasos sucesivos. Además, para incrementar el porcentaje de varianza explicada por los factores, los ratios que contenían información redundante también fueron eliminados del análisis. Todo el proceso fue realizado con el programa estadístico SPAD 6.0.

En cada sector, de acuerdo con el procedimiento descrito, se extrajeron seis factores. En el sector de la industria, 19 ratios se correlacionaban con los factores, que explicaban el $82,73 \%$ de la información original expresada por los 27 ratios financieros. En el sector de construcción, los seis factores extraídos explicaban el $84,86 \%$ de la varianza, correlacionándose con ellos 18 ratios. Por último, en el sector servicios, el porcentaje de varianza explicada fue del $70,96 \%$, siendo 19 los ratios correlacionados con los seis factores obtenidos.

Los ratios financieros correlacionados con los factores extraídos en cada sector se recogen en la Tabla 4. A su vez, se muestra la definición dada a los diferentes factores, según las correlaciones entre ratios y factores.

Como puede observarse, hay varios factores (y ratios relacionados) que son comunes a las tres submuestras. Estos
First of all, the analysis was applied to both the financial and external information, but it was observed a clearly different behaviour among financial ratios, on the one hand, and external variables, on the other. Consequently, we decided to run the analysis separately with the variables belonging to each group.

In the case of financial information, PCA was applied on the initial list of 27 financial ratios, referred to the last year of the study period. Those ratios which did not correlate with any of the obtained factors were deleted in successive steps. Moreover, to increase the variance percentage explained by the factors, ratios containing redundant information were also removed from the analysis. The whole process was made with the statistical software SPAD 6.0.

In each industry, according to the described procedure, six factors were finally obtained. In the manufacturing industry, 19 ratios were correlated with the factors, which explained $82.73 \%$ of the original information expressed by the 27 financial ratios. In the building industry, the extracted six factors explained $84.86 \%$ of the variance and 18 ratios were correlated with any of them. Finally, in the service industries, the percentage of explained variance was $70.96 \%$, with 19 ratios being correlated to the six obtained factors.

The ratios correlated with the extracted factors in each industry are shown in Table 4. Furthermore, the description given to the different factors is also shown, according to the correlations between ratios and factors.

As it can be observed, there are some factors (and related ratios) that are common to the three subsamples. These 
son descritos como "estructura de recursos", puesto que está correlacionado con la proporción de fondos propios (NPA), deuda a corto plazo (RECP) y cashflow (CFAT) sobre activo total; la capacidad de las empresas para pagar deudas con sus propios recursos, bien generados de forma interna (CFDT, CFPC) o externa (FPPC); y "liquidez", ya que este factor se correlaciona con varios ratios que miden este aspecto de la actividad de la empresa. A este respecto, el ratio de liquidez inmediata (TES) representa un factor propio en los sectores de construcción y servicios. factors are described as: 'liability structure', since this factor is correlated to the proportion of equity (NPA), current debt (RECP) and cash-flow (CFAT) on total assets; the firms' ability to pay debts with their own resources, internally (CFDT, CFPC) or externally (FPPC) generated; and 'liquidity', as this factor is correlated to several ratios measuring this issue of the firm's activity. In this regard, the quick ratio (TES) represents a characteristic factor in the industries of building and service.

\section{Tabla 4. Factores explicativos y ratios que los caracterizan} Table 4. Factors from PCA and variables related

\begin{tabular}{|c|c|c|c|c|}
\hline \multirow{2}{*}{$\begin{array}{l}\text { Significado del factor } \\
\text { Factor description }\end{array}$} & \multicolumn{3}{|c|}{ Variables } & \\
\hline & $\begin{array}{c}\text { Industria } \\
\text { Manufacturing }\end{array}$ & $\begin{array}{l}\text { Construcción } \\
\text { Building }\end{array}$ & $\begin{array}{l}\text { Servicios } \\
\text { Service }\end{array}$ & \\
\hline \multirow{3}{*}{$\begin{array}{l}\text { Estructura de recursos } \\
\text { Liability structure }\end{array}$} & NPA & NPA & NPA & \\
\hline & CFAT & CFAT & CFAT & \\
\hline & RECP & RECP & RECP & \\
\hline \multirow{3}{*}{$\begin{array}{l}\text { Capacidad de devolución de } \\
\text { deuda / Ability to return debts }\end{array}$} & CFDT & CFDT & CFDT & \\
\hline & CFPC & CFPC & CFPC & \\
\hline & FPPC & FPPC & FPPC & \\
\hline \multirow{3}{*}{ Liquidez / Liquidity } & $\mathrm{RCl}$ & $\mathrm{RCl}$ & $\mathrm{RCl}$ & \\
\hline & LIQ & LIQ & LIQ & \\
\hline & PAC & PAC & PAC & \\
\hline Tesorería / Cash & TES & TES & TES & \\
\hline Circulante / Current position & $\begin{array}{l}\mathrm{AC} \\
\mathrm{CCA}\end{array}$ & $\begin{array}{l}\mathrm{AC} \\
\mathrm{CCA}\end{array}$ & $\begin{array}{l}\mathrm{AC} \\
\mathrm{CCA}\end{array}$ & \\
\hline \multirow{4}{*}{ Rotación / Turnover } & PPAG & PPAG & PPAG & \\
\hline & GFV & GFV & - & \\
\hline & $\mathrm{CCV}$ & $\mathrm{CCV}$ & - & \\
\hline & RAC & - & RAC & \multirow{2}{*}{$\begin{array}{c}\text { Margen de } \\
\text { beneficios } \\
\text { Profit margin }\end{array}$} \\
\hline \multirow{2}{*}{$\begin{array}{l}\text { Rentabilidad económica } \\
\text { Economic profitabililty }\end{array}$} & ROA & $\mathrm{ROA}$ & ROA & \\
\hline & - & ROAll & - & \\
\hline Fondos propios / Equity & $\begin{array}{l}\text { ROE } \\
\text { CCFO } \\
-\end{array}$ & $\begin{array}{l}- \\
- \\
-\end{array}$ & $\begin{array}{l}\text { ROE } \\
\text { CCFO } \\
\text { EQUI }\end{array}$ & \\
\hline $\begin{array}{l}\text { Rentabilidad de accionistas } \\
\text { Stakeholders profitability }\end{array}$ & - & REAC & REAC & \\
\hline
\end{tabular}


Otro factor común a las tres submuestras es el denominado "circulante", pues está correlacionado con los ratios de activo circulante (AC) y capital circulante (CCA) sobre activo total en los tres sectores, aunque en el de servicios, también se correlaciona con este factor el ratio PPAG. Dado que este ratio mide la rotación del activo circulante, en los otros dos sectores contribuye, junto con otros ratios que reflejan la rotación de diferentes partidas contables (GFV, CCV), a crear un factor definido como "rotación".

Un factor denominado "fondos propios" también es común a los sectores industrial y de servicios, mientras que éste último comparte con el de construcción un factor definido por la rentabilidad de accionistas (REAC).

Por último, podemos distinguir algunos factores específicos de un sector. En la construcción, se extrae un factor denominado "rentabilidad económica", ya que está correlacionado con los dos ratios que miden este aspecto (ROA, ROAll). En el sector servicios, ROA y la rotación del activo total (RAC) definen el factor "margen de beneficios".

Por lo que respecta a la información externa, los resultados del ACP son similares en los tres sectores, lo que es lógico, puesto que estas variables reflejen el entorno económico en el que las empresas desarrollan su actividad y es el mismo para todas las empresas, cualquiera que sea su actividad.

En cada sector, todas las variables se correlacionaron con los dos primeros factores extraídos, que explicaban más del $90 \%$ de la información original expresada por las ocho variables externas. En concreto, esos porcentajes fueron del $96,11,95,45$ y $91,74 \%$ de la varianza en los sectores de industria, construcción y servicios, respectivamente.
Another common factor to the three subsamples is the one termed as 'current position', provided it is correlated to the ratios of current assets $(A C)$ and working capital (CCA) on total assets in the three industries. In the service industries the PPAG ratio is also correlated with this factor. Since this ratio measures the current assets turnover, in the other two industries it contributes, together with some other ratios reflecting the turnover of different accounting entries (GFV, (CV), to create a 'turnover' factor.

An 'equity' factor is also common to the manufacturing and the service industries, whereas the latter shares with the building industry a factor defined by the stakeholders' profitability (REAC).

Finally, some specific factors to an industry can be distinguished. In the building industry, a factor named as 'economic profitability' is extracted, provided it is correlated to the two ratios measuring this issue (ROA, ROAII). In the service industries, ROA and total assets turnover (RAC) define the 'profit margin' factor.

Regarding the external information, PCA results were similar in the three industries, which is logical since these variables reflect the economic environment in which firms develop their activity and this is the same for every firm, whatever its activity is.

In each industry, all the variables were correlated with the first two extracted factors, which explained more than 90\% of the original information expressed by the eight external variables. Specifically, those percentages were 96.11, 95.45 and $91.74 \%$ of the variance in the manufacturing, building and service industries, respectively. 
El primer factor fue definido como "actividad económica general" (FAC1_EXT), ya que se correlacionaba con el PIB, el tipo de interés, el Índice de Precios Industriales a nivel nacional y las tasas de actividad nacional y en Castilla y León, mientras que el segundo factor se correlacionaba con los Índices de Precios de Consumo e Industriales en Castilla y León, además del Índice de Precios de Consumo a nivel nacional, por lo que se denominó "nivel de precios" (FAC2_EXT).

\subsection{Resultados de la predicción}

Con el fin de predecir el fracaso empresarial de las empresas en cada submuestra, aplicamos un análisis discriminante. A pesar de los supuestos estadísticos exigidos, este análisis es uno de los métodos estadísticos más utilizados en el campo del fracaso empresarial, donde se han obtenido buenos resultados de predicción.

Los ratios financieros correlacionados con los factores extraídos por el ACP en cada sector y los dos factores que resumen la información externa, junto con las mencionadas variables relativas a la empresa, se consideraron como variables predictoras para estimar los diferentes modelos. Respecto a la información financiera, decidimos incluir los ratios medidos en los tres años de nuestro periodo de estudio, evitando de este modo el inconveniente de obtener un modelo para cada año del periodo de tres. El programa estadístico SPSS 19 se utilizó para desarrollar los modelos predictivos, que se obtuvieron aplicando un procedimiento sucesivo por pasos hacia delante considerando cualquiera de los criterios de selección de variables disponibles en el programa.
The first factor was defined as 'general economic activity' (FAC1_EXT), as it was correlated to GNP, interest rate, national producer price index, and both national and Castile and León activity rates, while the second one was correlated with both consumer and producer price indexes in Castile and León, as well as the national consumer price index, so it was named as 'price level' (FAC2_EXT).

\subsection{Prediction results}

In order to predict the failure of the firms in each subsample, discriminant analysis was applied. Despite its required statistical assumptions, this analysis is one of the most used statistical methods in business failure field, generally obtaining good prediction results.

The financial ratios correlated with the six extracted factors by PCA in each industry and the two factors summarizing the external information, together with the mentioned firm-related variables, were used as predictor variables in order to estimate the different models. Regarding financial information, we decided to include the ratios measured in the three years of our study period, avoiding in this way the drawback of obtaining a model for each year of the three-year period. Statistical software SPSS 19 was used to develop the prediction models, which were obtained applying a forward stepwise procedure according to any of the variable selection criteria available in the software. 
Tabla 5. Resultados del análisis discriminante (Industria) Table 5. Disc riminant analysis results (Manufacturing industry)

\begin{tabular}{|c|c|c|c|c|c|}
\hline \multirow{2}{*}{ Variable } & \multicolumn{2}{|c|}{$\begin{array}{l}\text { Coeficientes de la función discriminante } \\
\text { Discriminant function coefficients }\end{array}$} & \multirow{2}{*}{$\begin{array}{c}\text { F parcial } \\
\text { Partial } \\
\text { F-value }\end{array}$} & \multirow{2}{*}{$\begin{array}{l}\text { Valor } p \\
P \text {-value }\end{array}$} & \multirow{2}{*}{$\begin{array}{c}\text { Coeficientes de } \\
\text { estructura } \\
\text { Structure } \\
\text { coefficients }\end{array}$} \\
\hline & $\begin{array}{l}\text { No estandarizados } \\
\text { Non-standardized }\end{array}$ & $\begin{array}{l}\text { Estandarizados } \\
\text { Standardized }\end{array}$ & & & \\
\hline FAC1_EXT & $-0,3233$ & $-0,7433$ & 20,4272 & 0,0000 & $-0,500$ \\
\hline CFAT & $-1,7077$ & $-0,4156$ & 3,3078 & 0,0744 & $-0,375$ \\
\hline FORMA & $-1,3851$ & $-0,6153$ & 12,4693 & 0,0008 & $-0,379$ \\
\hline NPA & $-0,0142$ & $-0,5638$ & 6,2835 & 0,0152 & $-0,424$ \\
\hline $\begin{array}{l}\text { Constante } \\
\text { Constant }\end{array}$ & 0,9832 & - & - & - & - \\
\hline
\end{tabular}

Los resultados del análisis discriminante para el sector industrial se recogen en la Tabla 5. Cuatro variables entraron en la función discriminante, por su significación en la predicción del fracaso empresarial en este sector, aunque el ratio de cashflow sobre activo total referido al último año anterior al fracaso (CFAT) sólo es significativo a un nivel del $10 \%$, como indica el valor $p$ asociado al estadístico $F$ parcial. Las otras variables significativas son el porcentaje de fondos propios sobre activo total el mismo año (NPA), la variable que indica si la empresas es una Sociedad de Responsabilidad Limitada (FORMA) y uno de los factores externos, en concreto el denominado "actividad económica general" (FAC1_EXT). De acuerdo con los coeficientes estandarizados y de estructura, la variable más importante en la función discriminante es el factor externo, seguido de la FORMA y los dos ratios financieros. Todas las variables significativas tienen una influencia negativa en la variable dependiente, esto es, en la puntuación discriminante, como también indica el signo de los coeficientes.
Discriminant analysis results for the manufacturing industry are shown in Table 5. Four variables entered the discriminant function, because of their significance in predicting business failure in this industry, although the ratio of cash-flow on total assets referred to the last year before failure (CFTA) is only significant at a $10 \%$ level, as the $p$-value associated to the partial $F$ shows. The other significant variables are the percentage of equity on total assets the same year (NPA), the variable indicating if the firm is Ltd (FORMA), and one of the external factors, specifically the one named as 'general economic activity' (FAC1_EXT). According to the structure and standardized coefficients, the most important variable in the discriminant function is this external factor, followed by FORMA and both financial ratios. All the significant variables have a negative influence on the dependent variable, that is, the discriminant score, as the sign of the coefficients also means. 
La Tabla 6 muestra los resultados del análisis discriminante llevado a cabo en la submuestra de empresas de la construcción. En este caso, cinco variables resultaron significativas. Se trata del mismo factor externo que en la industria y de cuatro ratios financieros: la proporción de capital circulante sobre activo total (CCA) el último año previo al fracaso y tres ratios medidos el año anterior: los porcentajes de cash-flow (CFAT_1) y deuda a corto plazo (RECP_1) sobre activo total y la rentabilidad de accionistas (REAC_1).
Table 6 shows the results from the discriminant analysis carried out on the building subsample. In this case, five variables became significant. They are the same external factor than in the manufacturing industry and four financial ratios: the proportion of working capital on total assets (CCA) the last year previous to failure, and three more ratios measured the year before: the percentages of cash-flow (CFAT 1) and current debt (RECP 1) on total assets, and the stakeholders' profitability (REAC_1).

\section{Tabla 6. Resultados del análisis discriminante (Construcción) Table 6. Discriminant analysis results (Building industry)}

\begin{tabular}{|c|c|c|c|c|c|}
\hline \multirow{2}{*}{ Variable } & \multicolumn{2}{|c|}{$\begin{array}{l}\text { Coeficientes de la función discriminante } \\
\text { Discriminant function coefficients }\end{array}$} & \multirow{2}{*}{$\begin{array}{l}\text { F parcial } \\
\text { Partial } \\
\text { F-value }\end{array}$} & \multirow{2}{*}{$\begin{array}{l}\text { Valor } p \\
P \text {-value }\end{array}$} & \multirow{2}{*}{$\begin{array}{c}\text { Coeficientes de } \\
\text { estructura } \\
\text { Structure } \\
\text { coefficients }\end{array}$} \\
\hline & $\begin{array}{l}\text { No estandarizados } \\
\text { Non-standardized }\end{array}$ & $\begin{array}{l}\text { Estandarizados } \\
\text { Standardized }\end{array}$ & & & \\
\hline FAC1_EXT & $-0,6756$ & $-0,6811$ & 18,1094 & 0,0001 & $-0,580$ \\
\hline RECP_1 & 0,0174 & 0,4315 & 5,8854 & 0,0188 & 0,351 \\
\hline REAC_1 & 0,0092 & 0,5080 & 8,0288 & 0,0066 & 0,319 \\
\hline CCA & $-1,9514$ & $-0,5569$ & 8,4460 & 0,0054 & $-0,099$ \\
\hline CFAT_1 & $-6,9172$ & $-0,5245$ & 8,3399 & 0,0057 & $-0,450$ \\
\hline $\begin{array}{l}\text { Constante } \\
\text { Constant }\end{array}$ & 0,4450 & - & - & - & - \\
\hline
\end{tabular}

Como puede observarse en la Tabla, la variable más importante en la función es, de nuevo, el factor externo que resume la actividad económica general y a continuación la proporción de capital circulante y de cash-flow, todos con influencia negativa en la variable dependiente. Los otros dos ratios tienen coeficientes positivos, lo que implica una relación directa con la puntuación discriminante.
As it can be observed in the Table, the most important variable in the function is again the external factor summarizing the general economic activity, and next the proportion of working capital and cash-flow, all with a negative influence on the dependent variable. The other two ratios have positive coefficients, which involve a direct relationship with the discriminant score. 


\section{Tabla 7. Resultados del análisis discriminante (Senvicios) Table 7. Discriminant analysis results (Senvice industries)}

\begin{tabular}{|c|c|c|c|c|c|}
\hline \multirow{2}{*}{ Variable } & \multicolumn{2}{|c|}{$\begin{array}{l}\text { Coeficientes de la función discriminante } \\
\text { Discriminant function coefficients }\end{array}$} & \multirow{2}{*}{$\begin{array}{c}\text { F parcial } \\
\text { Partial } \\
\text { F-value }\end{array}$} & \multirow{2}{*}{$\begin{array}{l}\text { Valor } p \\
\text { P-value }\end{array}$} & \multirow{2}{*}{$\begin{array}{c}\text { Coeficientes de } \\
\text { estructura } \\
\text { Structure } \\
\text { coefficients }\end{array}$} \\
\hline & $\begin{array}{l}\text { No estandarizados } \\
\text { Non-standardized }\end{array}$ & $\begin{array}{l}\text { Estandarizados } \\
\text { Standardized }\end{array}$ & & & \\
\hline CFAT & $-2,6404$ & $-0,6152$ & 27,9982 & 0,0000 & $-0,427$ \\
\hline FAC2 EXT & 0,3938 & 0,6659 & 33,3676 & 0,0000 & 0,409 \\
\hline CFAT_1 & $-3,6436$ & $-0,4610$ & 14,4806 & 0,0002 & $-0,344$ \\
\hline EQUI_2 & 0,0117 & 0,5367 & 19,6864 & 0,0000 & 0,259 \\
\hline VIDA & 0,0050 & 0,4854 & 15,7598 & 0,0001 & 0,250 \\
\hline RECP & 0,0082 & 0,2710 & 4,5569 & 0,0346 & 0,171 \\
\hline $\begin{array}{l}\text { Constante } \\
\text { Constant }\end{array}$ & $-1,0793$ & - & - & - & - \\
\hline
\end{tabular}

Por último, los resultados respecto al sector servicios se recogen en la Tabla 7. La función discriminante está definida por seis variables que, según el valor $p$ asociado a cada una, son significativas. La información externa vuelve a ser importante en predecir el fracaso empresarial aunque en este sector es el "nivel de precios" el factor significativo. El tiempo desde la constitución de la empresa (VIDA) también entró en el modelo, junto con cuatro ratios financieros, medidos en los tres años del periodo en estudio: el porcentaje de deudas a corto plazo sobre activo total (RECP) referido al último año previo al fracaso, el ratio de cash-flow sobre activo total tanto este año (CFAT) como el anterior (CFAT_1), y la proporción de fondos propios y fondos ajenos a largo plazo que financian el activo fijo el tercer año previo al fracaso (EQUI_2). Según los coeficientes en la tabla, sólo el ratio de cash-flow tiene una influencia negativa en la variable dependiente, mientras que los coeficientes correspondientes al resto de variables tienen signo positivo. Dicho ratio y el factor externo que describe al nivel de precios son las variables más importantes en la función discriminante, de acuerdo con los coeficientes estandarizados y de estructura.
Finally, results regarding the service industries are shown in Table 7 . The discriminant function is defined by the six variables that, according to the $p$-value associated to each one, are significant. External information is again important in predicting business failure, although in this industry the 'level price' (FAC2_EXT) is the significant factor. The time from the firms incorporation date (VIDA) also entered the model, as well as four financial ratios, measured in the three years of our study period: the percentage of current liabilities on total assets (RECP) referred to the last year before failure, the ratio of cash-flow on total assets both that year (CFAT) and the previous one (CFAT_1), and the proportion of equity and fixed liabilities that finance fixed assets the third year before failure (EQUI_2). According to the coefficients in the table, only the ratio of cash-flow has a negative influence on the dependent variable, whereas the coefficients corresponding to the rest of variables have a positive sign. That ratio and the external factor which describes the level price are the most important variables in the discriminant function, according to both the standardized and structure coefficients. 
A la vista de los resultados recogidos en las Tablas 5 a 7, pueden extraerse algunas conclusiones respecto al fracaso empresarial en los tres sectores:

- La información externa es importante en la explicación y predicción del fracaso empresarial, dado que uno de los dos factores que resumen esta clase de información ha resultado significativo en cada sector. Mientras que la actividad económica general tiene influencia en los sectores de industria y construcción, el factor que mide el nivel de precios es el significativo para las empresas que operan en el sector servicios, lo que es lógico, dada la clase de actividad que desarrollan.

- La información no financiera también es significativa en el fracaso empresarial, al menos en dos de los tres sectores considerados. En la industria, es la variable que distingue entre Sociedades Anónimas y de Responsabilidad Limitada la que entra en el modelo. Por otro lado, la vida de las empresas en el sector servicios tiene un efecto significativo sobre la variable dependiente en esta submuestra.

- Respecto a la información financiera, varios ratios han resultados significativos en los modelos elaborados para cada sector. La proporción de cash-flow sobre activo total en uno de los dos años anteriores al momento del fracaso forma parte de la función discriminante en las tres submuestras, lo que indica la importancia de generar recursos internamente a efectos de evitar el fracaso empresarial.

- Además de estos aspectos comunes, también hay algunas diferencias entre los distintos sectores. La función discriminante en la industria se completa con un ratio que refleja la importancia de los fondos propios. En el sector de construcción, hay otros tres ratios significativos
By observing the results in Tables 5 to 7 , some conclusions about business failure in the three industries can be drawn:

- External information is important in explaining and predicting business failure, since one of the two factors summarizing this kind information have become significant in each industry. Whereas the general economic activity has influence on both the manufacturing and building industries, the factor measuring the price level is the significant one for the firms operating in the service industries, which is logical, provided the kind of activities they develop.

- Non-financial information is also significant in business failure, at least in two out of the three considered industries. In the manufacturing one, it is the variable distinguishing between public and private limited companies which enters the prediction model. On the other hand, the age of the firms in the service industries has a significant effect on the dependent variable in this subsample.

- Regarding financial information, several ratios have become significant in the developed models in each industry. The proportion of cash-flow on total assets for one of the two last years before failure is part of the discriminant function in the three subsamples, which shows the importance of generating internally resources in order to avoid business failure.

- As well as these common issues, there are some differences among the various industries. The discriminant function in the manufacturing industry is completed with a ratio reflecting the importance of equity. In the building one, there are three more significant ratios which measure the stakeholders' profitability and current issues of the firm, whereas 
que miden la rentabilidad de accionistas y aspectos de circulante de la empresa, mientras que en los servicios, además del pasivo circulante, también es significativo el nivel de solvencia.

Una vez estimados los modelos predictivos, las empresas en cada submuestra sectorial fueron clasificadas como fracasadas o no fracasadas a partir de la información proporcionada por las variables significativas en cada función discriminante. Los resultados de clasificación se recogen en la Tabla 8. Como puede observarse, son bastante similares en los tres sectores, si bien los mejores resultados se obtienen en la construcción, tanto en cada grupo de empresas como en la submuestra total.

En los tres sectores, se alcanzan buenos resultados de clasificación, con un alto porcentaje de empresas sanas correctamente clasificadas, en especial en el sector de la construcción, donde la tasa de aciertos es del $100 \%$. Por lo que se refiere a las empresas fracasadas, los porcentajes de clasificación correcta son bastante altos, si tenemos en cuenta la composición muestral. Dado que el porcentaje de empresas fracasadas en las diferentes submuestras es bastante bajo en comparación con el de empresas no fracasadas, es normal que las tasas de aciertos para el primer grupo no sean tan altas. En todo caso, todos los porcentajes son superiores al 50\%, llegando incluso a más del $80 \%$, como puede observarse respecto al sector de la construcción. in the service industries, as well as current liabilities, solvency issues are also significant.

Once the prediction models were developed, firms in each industry subsample were classified as either failed or non-failed using the information provided by the significant variables in each discriminant function. The classification results are shown in Table 8 . As it can be observed, they are quite similar in the three industries, but the best results are achieved in the building one, both in each firms group and in the total subsample.

In the three industries, good classification results are achieved, with a very high percentage of well classified non-failed firms, especially in the building industry, where the hit rate is $100 \%$. Regarding the failed firms, the correct classification percentages are quite high, if we take into account the sample composition. Provided the percentage of failed firms in the subsamples is quite low in comparison to the non-failed firms one, it is normal that the correct classification results among the former group are not so good. In any case, all the rates are higher than 50\%, even achieving more than $80 \%$, as it can be observed regarding the building industry.

Tabla 8. Resultados de clasificación / Table 8. Classification results

\begin{tabular}{|c|c|c|c|}
\hline \multirow{2}{*}{ Empresas / Firms } & \multicolumn{3}{|c|}{ SECTOR I INDUSTRY } \\
\hline & Industria I Manufacturing & Construcción / Building & Servicios / Service \\
\hline Fracasadas / Failed & $59,09 \%$ & $83,33 \%$ & $70,59 \%$ \\
\hline No fracasadas / Non-failed & $94,92 \%$ & $100 \%$ & $95,81 \%$ \\
\hline Total & $85,19 \%$ & $97,85 \%$ & $93,97 \%$ \\
\hline
\end{tabular}


Por consiguiente, los ratios financieros, junto con información no financiera tanto relativa a la empresa como externa a la misma, son útiles como variables para predecir el fracaso empresarial. La inclusión de estos tipos de información en los modelos de predicción del fracaso mediante la aplicación del análisis discriminante lleva a buenos resultados de clasificación en los tres sectores analizados, mostrando que este método predictivo es adecuado en el campo del fracaso empresarial.

\section{CONCLUSIONES}

Nuestro estudio se ha centrado en el análisis del fracaso empresarial por sectores, con el fin de determinar los factores diferenciadores del fracaso en cada sector. Para ello, hemos aplicado uno de los métodos estadísticos más utilizados en este campo, el análisis discriminante, que ha mostrado su capacidad para predecir el fracaso en muestras correspondientes a diferentes periodos y países. Debido a la robustez de la técnica, permite obtener buenos resultados de clasificación, incluso cuando no se cumplen las hipótesis exigidas para su aplicación.

Para seleccionar la muestra de estudio, nos hemos centrado en las empresas con domicilio social en Castilla y León cuya información estaba disponible en la base de datos $S A B I$ utilizada para recoger los datos, correspondientes tanto a variables financieras como no financieras relativas a la empresa, además de información externa. La muestra seleccionada aplicando un procedimiento mixto aleatorio y no aleatorio fue dividida en tres sectores principales: industria, construcción y servicios.
Therefore, financial ratios together with non-financial both firm-related and external information are very useful as variables in order to predict business failure. The inclusion of all these kinds of information in prediction models by the application of a discriminant analysis leads to good classification results in the three analysed industries, showing that this predictive method is appropriate in business failure field.

\section{CONCLUSIONS}

Our study has focused on a crossindustry analysis of business failure, with the aim of identifying the differential failure factors in each industry. In order to do that, one of the main statistical methods in this field has been applied: discriminant analysis, which has shown its ability to predict business failure in samples corresponding to different periods and countries. Because of the robustness of this technique, it allows obtaining good classification results, even though the required hypotheses for its application are not achieved.

To select the study sample, we focused on firms with head offices in the region of Castile and León (Spain) whose information was available in the database $\mathrm{SABI}$ which was used to collect the data referring to both financial and nonfinancial firm-related variables, together with external information. The selected sample, applying a combined random and non-random procedure, was divided into three main industries: manufacturing, building and service. 
Antes de obtener los modelos discriminantes para predecir el fracaso empresarial en cada uno de esos sectores, aplicamos previamente un ACP, con el fin de reducir el número de ratios financieros y la información externa seleccionada como variables potencialmente explicativas para nuestro estudio.

Para resumir las variables externas, en los tres sectores se obtuvieron dos factores, definidos como "actividad económica general" y "nivel de precios". Respecto a la información financiera, algunos factores extraídos fueron comunes a todos los sectores: estructura de recursos, capacidad para devolver deudas, liquidez y circulante. Pero también definimos otros factores específicos de cada sector, como la rentabilidad económica en el sector de la construcción, el margen de beneficios en el de servicios o los fondos propios, tanto en la industria como en los servicios.

Por lo que se refiere a los resultados de la predicción, tanto las variables externas como las no financieras relativas a la empresa resultaron significativas en las funciones discriminantes para cada sector, lo que confirma la importancia de este tipo de información en la predicción del fracaso empresarial. Los aspectos financieros también resultaron significativos en los tres modelos, en los que el más importante fue la capacidad de la empresa para generar recursos internamente. Otros aspectos significativos para evitar el fracaso fueron los siguientes: los fondos propios, en la industria; la rentabilidad y aspectos de circulante, en la construcción y la solvencia, en el sector servicios.

Toda la información contenida en las funciones discriminantes fue utilizada para clasificar las empresas de cada sector como fracasadas o no fracasadas. Los resultados de clasificación fueron buenos en los tres sectores, aunque los
Before developing the discriminant models to predict business failure in each of those industries, a previous PCA was applied, in order to reduce the number of financial ratios and external information selected as potentially explanatory variables for our study.

To summarize the external variables, two factors defined as 'general economic activity' and 'price level' were obtained in the three industries. Regarding the financial information, some extracted factors were common to all the industries: liability structure, ability to return debts, liquidity and current position. But some other industry-specific factors were defined, such as economic profitability in the building industry, profit margin in the service ones or equity in both the manufacturing and the service industries.

With regard to the prediction results, both external and non-financial firmrelated variables became significant in the discriminant functions for each industry, which confirms the importance of this kind of information in predicting business failure. Financial issues were also significant in the three models, being the most important one the firm's ability to generate internally resources. Other significant issues in order to avoid failure are the following: equity, in the manufacturing industry; profitability and current issues in the building one, and solvency, in the service industries.

All the information in the discriminant functions was used to classify the firms in each industry as failed or non-failed. The classification results were good in the three industries, although the highest hit rates were achieved in the building one. 
porcentajes más altos se alcanzaron en el de la construcción. En todo caso, los resultados fueron mejores en el grupo de empresas sanas que en el de fracasadas, lo que puede explicarse por la composición de cada submuestra, con un mayor porcentaje de ese tipo de empresas.
In any case, the results were better regarding the non-failed group than the failed one, which can be explained because of each subsample composition, with a higher percentage of that kind of firms.

\section{BIBLIOGRAFÍA / REFERENCES}

Altman, E.I. (1968). Financial ratios, discriminant analysis and the prediction of corporate bankruptcy. The Journal of Finance, XXIII(4), 589-609.

Altman, E.I. (1984). The success of business failure models: An international survey. Journal of Banking \& Finance, 8, 171-198.

Altman, E.I., Marco, G. y Varetto, F. (1994). Corporate distress diagnosis: Comparisons using linear discriminant analysis and neural networks (the Italian experience). Journal of Banking \& Finance, 18, 505-529.

Balcaen, S. y Ooghe, H. (2006). 35 years of studies on business failure: An overview of the classical statistical methodologies and their related problems. The British Accounting Review, 38(1), 63-93.

Beaver, W.H. (1966). Financial ratios as predictors of failure. Journal of Accounting Research, Supplement to vol. 4: Empirical research in accounting: Selected studies, 71-111.

Blum, M. (1974). Failing company discriminant analysis. Journal of Accounting Research, Spring, $1-25$.

Charitou, A., Neophytou, E. y Charalambous, C. (2004). Predicting corporate failure: Empirical evidence for the UK. European Accounting Review, 13(3), 465-497.

Chava, S. y Jarrow, R.A. (2004). Bankruptcy prediction with industry effects. Review of Finance, 8 , 537-569.

Cybinski, P. (2001). Description, explanation, prediction - the evolution of bankruptcy studies? Managerial Finance, 27(4), 29-44.

Deakin, E.B. (1972). A discriminant analysis of predictors of business failure. Journal of Accounting Research, spring, 161-179.

Dimitras, A.l., Slowinski, R., Susmaga, R. y Zopounidis, C. (1999). Business failure prediction using rough sets. European Journal of Operational Research, 114(2), 263-280.

Dimitras, A.I., Zanakis, S.H. y Zopounidis, C. (1996). A survey of business failures with an emphasis on prediction methods and industrial applications. European Journal of Operational Research, 90(3), 487-513.

Edmister, R.O. (1972). An empirical test of financial ratio analysis for small business failure prediction. Journal of Financial and Quantitative Analysis, 7, march, 1477-1493. 
Elam, R. (1975). The effect of lease data on the predictive ability of financial ratios. The Accounting Review, 50(1), 25-43.

Izan, H.Y. (1984). Corporate distress in Australia. Journal of Banking and Finance, 8, 303-320.

Jones, F.L. (1987). Current techniques in bankruptcy prediction. Journal of Accounting Literature, 6, 131-164.

Junta de Andalucía (2004). Tejido empresarial y factores de éxito. Una aproximación al caso andaluz. Sevilla: Servicio de Asesoría Técnica y Publicaciones. Consejería de Economía y Hacienda.

Keasey, K. y Watson, R. (1991). Financial distress prediction models: A review of their usefulness. British Journal of Management, 2(2), 89-102.

Laffarga Briones, J., Martín Marín, J.L. y Vázquez Cueto, M.J. (1985). El análisis de la solvencia en las instituciones bancarias: Propuesta de una metodología y aplicaciones a la Banca española. ESIC-MARKET, 48, abril-junio, 51-73.

Laitinen, E.K. (1991). Financial ratios and different failure processes. Journal of Business, Finance \& Accounting, 18(5), 649-673.

Laitinen, E.K. y Laitinen, T. (1998). Misclassification in bankruptcy prediction in Finland: Human information processing approach. Accounting, Auditing \& Accountability Journal, 11(2), 216244.

Lang, L.H.P. y Stulz, R.M. (1992). Contagion and competitive intra-industry effects of bankruptcy announcements. Journal of Financial Economics, 32, 45-60.

Lincoln, M. (1984). An empirical study of the usefulness of accounting ratios to describe levels of insolvency risk. Journal of Banking and Finance, 8, 321-340.

McDonald, B. y Morris, M.H. (1984). The statistical validity of the ratio method in financial analysis: An empirical examination. Journal of Business Finance \& Accounting, 11(1), 89-96.

Mora Enguídanos, A. (1994). Los modelos de predicción del fracaso empresarial: una aplicación empírica del logit. Revista Española de Financiación y Contabilidad, XXIII(78), 203-233.

Odom, M.D. y Sharda, R. (1992). A neural network model for bankruptcy prediction. En, R.R. Trippi y E. Turban (Eds.), Neural networks in finance and investing. Using artificial intelligence to improve real-world performance (pp. 177-185). Cambridge: Probus Publishing Company.

Ohlson, J.A. (1980). Financial ratios and the probabilistic prediction of bankruptcy. Journal of Accounting Research, 18(1), 109-131.

Palepu, K.G. (1986). Predicting takeover targets. A methodological and empirical analysis. Journal of Accounting and Economics, 8, 3-35.

Peel, M.J., Peel, D.A. y Pope, P.F. (1986). Predicting corporate failure - some results for the UK corporate sector. Omega, International Journal of Management Science, 14(1), 5-12.

Pina Martínez, V. (1989). La información contable en la predicción de la crisis bancaria 1977-1985. Revista Española de Financiación y Contabilidad, XVIII(58), 309-338. 
Platt, H.D. y Platt, M.B. (1990). Development of a class of stable predictive variables: The case of bankruptcy prediction. Journal of Business Finance \& Accounting, 17(1), 31-51.

Platt, H.D. y Platt, M.B. (1991). A note on the use of industry-relative ratios in bankruptcy prediction. Journal of Banking and Finance, 15(6), 1183-1194.

Ravi Kumar, P. y Ravi, V. (2007). Bankruptcy prediction in banks and firms via statistical and intelligent techniques - A review. European Journal of Operational Research, 180(1), 1-28.

Román Martínez, I., de la Torre Martínez, J.M. y Zafra Gómez, J.L. (2001). Análisis sectorial de la predicción del riesgo de insolvencia: Un estudio empírico. XI Congreso AECA "Empresa, Euro y Nueva Economía". Madrid, 26-28 de septiembre.

Smith, M. y Liou, D.K. (2007). Industrial sector and financial distress. Managerial Auditing Journal, 22(4), 376-391.

Taffler, R.J. (1982). Forecasting company failure in the UK using discriminant analysis and financial ratio data. Journal of the Royal Statistical Society, Series A - Statistics in Society, 145(3), 342-358.

Taylor, J.D. (1997/1998). Cross-industry differences in business failure rates: Implications for portfolio management. Commercial Lending Review, 13(1), 36-46.

Theodossiou, P.T. (1991). Alternative models for assessing the financial condition of business in Greece. Journal of Business, Finance \& Accounting, 18(5), 697-720.

Zmijewski, M.E. (1984). Methodological issues related to the estimation of financial distress prediction models. Journal of Accounting Research, Supplement to vol. 22, Studies on Current Econometric Issues in Accounting Research, 59-82. 